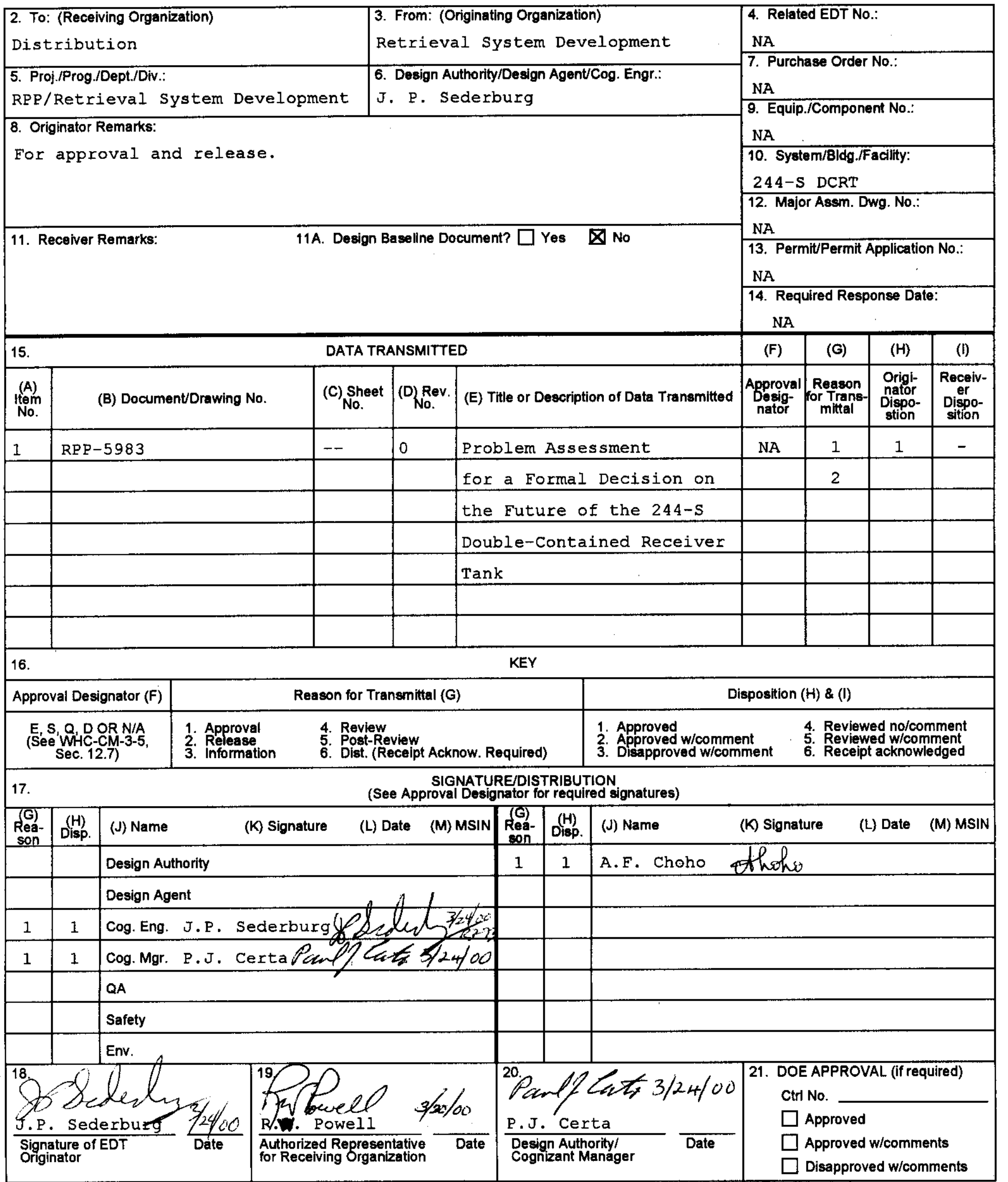




\title{
Problem Assessment for a Formal Decision on the Future of the 244-S Double-Contained Receiver Tank
}

\author{
J. Pete Sederburg, ARES Corporation \\ for Numatec Hanford Corporation \\ Richland, WA 99352 \\ U.S. Department of Energy Contract DE-AC06-99RL14047

$\begin{array}{lll}\text { EDT/ECN: } & 629058 & \text { UC: } 721 \\ \text { Cost Center: } & 6 \mathrm{~N} 100 & \text { Charge Code: } 110350 / \text { BAllo } \\ \text { B\&R Code: } & \text { EW3130000 } & \text { Total Pages: } 38\end{array}$

Key Words:

244-S, DCRT, Decision, AGA

\begin{abstract}
This document describes the background, concerns, and issues associated with continued use of the 244-S DCRT. A problem statement is defined such that management may in the future make a decision about the preferred path forward on this DCRT. Influences and potential answers are outlined and presented such that costs, waste volume projections, projects (such as $\mathrm{W}-314$ ), and other facilities (such as 222-S and PFP) are accurately represented.
\end{abstract}

TRADEMARK DISCLAIMER. Reference herein to any specific commercial product, process, or service by trade name, trademark, manufacturer, or otherwise, does not necessarily constitute or imply its endorsement, recommendation, or favoring by the United States Government or any agency thereof or its contractors or subcontractors.

Printed in the United States of America. To obtain copies of this document, contact: Document Control Services, P.O. Box 950, Mailstop H6-08, Richland WA 99352, Phone (509) 372-2420; Fax (509) 376-4989.
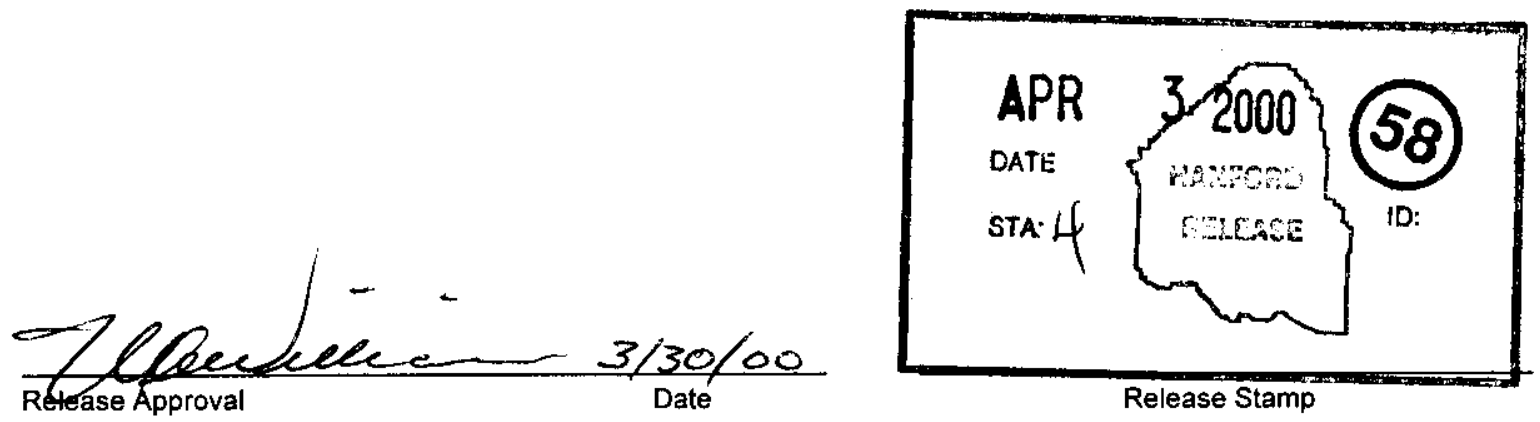

Approved For Public Release 
RPP-5983

Revision 0

\section{Problem Assessment for a Formal Decision on the Future of the 244-S Double- Contained Receiver Tank}

Prepared for the U.S. Department of Energy Assistant Secretary for Environmental Management

\section{CH2MHILL}

Hanford Group, Inc.

Richland, Washington 
LEGAL DISCLAIMER

This report was prepared as an account of work sponsored by an agency of the United States Government. Neither the United States Government nor any agency thereof, nor any of their employees, nor any of their contractors, subcontractors or their employees, makes any warranty, express or implied, or assumes any legal liability or responsibility for the accuracy, completeness, or any third party's use or the results of such use of any information, apparatus, product, or process disclosed, or represents that its use would not infringe privately owned rights. Reference herein to any specific commercial product, process, or service by trade name, trademark, manufacturer, or otherwise, does not necessarily constitute or imply its endorsement, recommendation, or favoring by the United States Government or any agency thereof or its contractors or subcontractors. The views and opinions of authors expressed herein do not necessarily state or reflect those of the United States Government or any agency thereof.

This report has been reproduced from the best available copy.

Available in paper copy and microfiche.

Available electronically at http://www.doe.gov/bridge. Available for a processing fee to the U.S. Department of Energy and its contractors, in paper, from:

U.S. Department of Energy

Office of Scientific and Technical Information

P.O. Box 62

Oak Ridge, TN 37831-0062

phone: 865-576-8401

fax: 865-576-5728

email: reports@adonis.osti.gov(423) 576-8401

Available for sale to the public, in paper, from:

U.S. Department of Commerce

National Technical Information Service

5285 Port Royal Road

Springfield, VA 22161

Phone: 800-553-6847

fax: 703-605-6900

email: orders@ntis.fedworld.gov

online ordering:

http:/www.ntis.gov/ordering.htm 
RPP-5983

Revision 0

\section{Problem Assessment for a Formal Decision on the Future of the 244-S Double- Contained Receiver Tank}

Prepared by:

J. Pete Sederburg

ARES Corporation

Richland, Washington

prepared for

Numatec Hanford Corporation

Richland, Washington

Date Published

March 2000

Prepared for the U.S. Department of Energy

Assistant Secretary for Environmental Management

\section{CH2MHILL}

Hanford Group, Inc.

P. O. Box 1500

Richland, Washington

Contractor for the U.S. Department of Energy

Office of River Protection under Contract DE-AC06-99RL14047 
RPP-5983 REV 0

This page intentionally left blank. 


\section{CONTENTS}

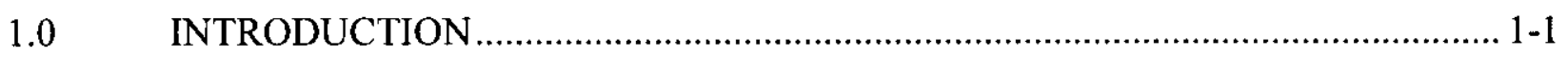

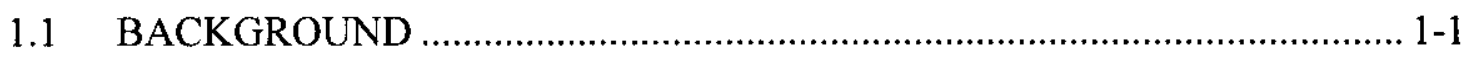

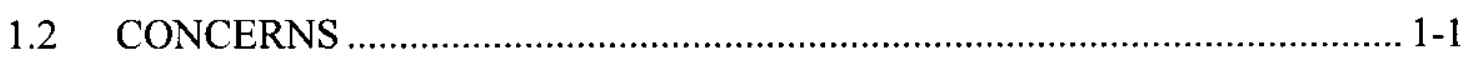

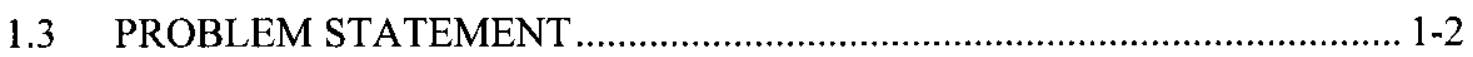

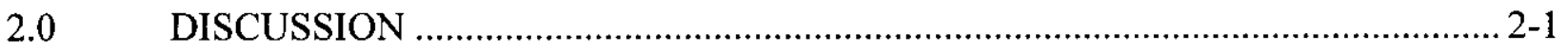

2.1 TANK FARMS UPGRADES AND OPERATION COSTS ………................ 2-1

2.2 OPERATIONAL WASTE VOLUME PROJECTIONS ................................. 2-3

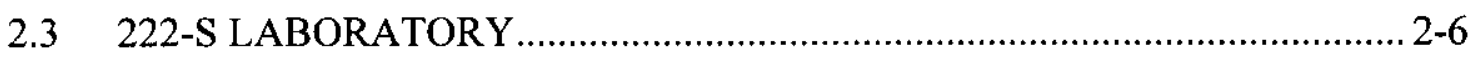

2.4 PLUTONIUM FINISHING PLANT ………….............................................. 2-9

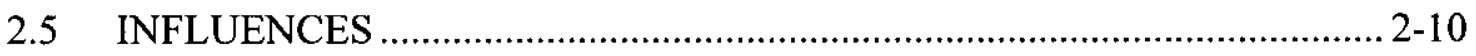

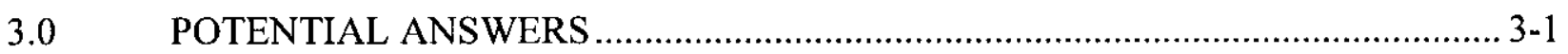

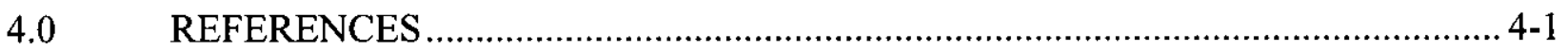

APPENDIX -DOCUMENTATION OF COST ESTIMATE................................................. A-1

\section{TABLES}

2-1. Baseline Acceptable Standard-of-Use Scenario for the 244-S Double-Contained Receiver Tank Transfer System.

2-2. 222-S Laboratory Waste Generation, Projections versus Actuals.*.

2-3. Projected Customer Waste Volumes and Compositions for the 200 West Area Tank Farms.

2-4. Nominal Customer Waste Compositions Converted to Common Units......................... 2-8

2-5. Potential Task Team for the 244-S Double-Contained Receiver Tank Transfer System

3-1. Development and Prescreening Processes for Alternatives 
RPP-5983 REV 0

\section{FIGURES}

1-1. Elevation View of Transfer Routes in 200 West Area Tank Farms............................ 1-3

1-2. Plan View of the 200 West Area Showing the Transfer System................................ 1-5

1-3. 200 West Area Tank Farm Pit Details............................................................... 1-7

2-1. Cumulative Plutonium Finishing Plant and 222-S Laboratory Waste Generations........ 2-4

2-2. 222-S Laboratory Waste Generations, Projections versus Actual............................ 2-5

2-3. Plutonium Finishing Plant Waste Generations, Projection versus Actual. ................... 2-5

2-4. 222-S Laboratory Liquid-Waste-Handling Scheme............................................. 2-8

2-5. Plutonium Finishing Plant Liquid-Waste-Handling Scheme............................... 2-10

2-6. Influence Diagram for Helping to Determine the Future of the 244-S DoubleContained Receiver Tank. 
RPP-5983 REV 0

\section{ABBREVIATIONS AND ACRONYMS}

244-S DCRT transfer system

222-S

CFR

DCRT

DST

HEPA

NESHAP

OWVP

PFP

WAC

W-087

W-178

W-314

W-420 comprises the 244-S DCRT, 244-S Pump Pit, 244-S Ventilation System, and 244-S Piping and Instrumentation System

222-S Laboratory

Code of Federal Regulations

double-contained receiver tank

double-shell tank

high-efficiency particulate air

National Emission Standards for Hazardous Air Pollutants operational waste volume projections

Plutonium Finishing Plant

Washington Administrative Code

Project: 222-S Radioactive Liquid Waste Line

Replacement

Project: 219-S Secondary Containment Upgrade

Project: Tank Farm Restoration and Safe Operations

Project: Major Exhaust Stack Monitoring Upgrades 
RPP-5983 REV 0

This page intentionally left blank. 


\subsection{INTRODUCTION}

This assessment defines and begins to frame the scope of a formal decision and associated alternatives generation and analysis to examine the methods used to transfer radioactive liquid waste from the 222-S Laboratory (222-S) and the Plutonium Finishing Plant (PFP) to the doubleshell tank (DST) system. Various methods, including the current pipeline routing system, are analyzed herein and should be examined and compared to determine their optimum lifecycle costs and benefits. The current transfer system configuration is shown graphically in Figures 1-1, 1-2, and 1-3.

\subsection{BACKGROUND}

Historically there has been a need at the Hanford Site to transfer radioactive hazardous liquid wastes away from generating facilities (e.g., 222-S and PFP). Liquid waste that was too radioactive and hazardous to send to cribs or treatment facilities (i.e., the 200 East Area Treatment Plant and the 200 Area Treated Effluent Disposal Facility) has been routed to the tank farms for storage.

Over time, some of the missions and strategies of the waste generators have evolved, reducing the volume of liquid radioactive wastes routed to the tank farms. The only remaining waste streams that appear viable for routing to the 200 West Area tank farms are produced by 222-S and PFP. Furthermore, the amount of waste produced at 222S and PFP and routed to the tank farms also has been reduced. A common waste-routing system is used by $222 \mathrm{~S}$ and PFP to route waste to Tank 241-SY-102 for storage. This common system routes waste through the 244-S double-container receiver tank (DCRT) transfer systems, transfer line V-562, the SY-A Valve Pit, transfer line SN-277, the SY-A Valve Pit, the SY-02A Pit, and finally into Tank 241-SY-102. The 244-S DCRT transfer system comprises the 244-S DCRT, 244-S Pump Pit, 244-S Ventilation System, and 244-S Piping and Instrumentation System.

Now that the amount of waste transferred to the tank farms has been reduced significantly, the future use of the 222-4 DCRT transfer system comes into question. Should the 244-S DCRT transfer system continue to be maintained? Alternatively, is there a more cost-effective way for the Hanford Site to continue to provide 222-S and PFP with the capability to dispose of their liquid radioactive wastes?

\subsection{CONCERNS}

There are three main concerns associated with the 244-S DCRT transfer system. Each of these concerns is stated below.

1. Quantity of Projected Waste Generations. There appears to be a declining need for the 244-S DCRT as a waste-handling system. The quantity of waste that 222-S and PFP plan to transfer through the 244-S DCRT transfer system is at a historical low. Furthermore, other waste generators that used the 244-S DCRT transfer system in the past are no longer expecting to need this facility (e.g., Single-Shell Tanks Interim Stabilization). 
2. Aging Equipment. The 244-S DCRT transfer system was constructed in the late 1970 s and early $1980 \mathrm{~s}$. The components of the transfer system are approaching, or have passed, their original intended design lives.

3. Regulatory Requirements. The requirements that have been, and are expected to be, imposed on the 244-S DCRT transfer system could result in substantially higher costs than anticipated to maintain a sufficient degree of compliance.

\subsection{PROBLEM STATEMENT}

This assessment will begin to frame a formal decision and associated alternatives generation and analysis to answer the following question:

"What approach for using or bypassing the 244-S DCRT is optimum for transferring waste from the 222-S Laboratory and the Plutonium Finishing Plant to tank farms?" 


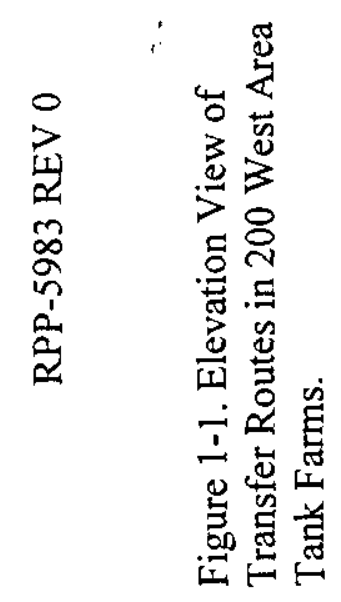
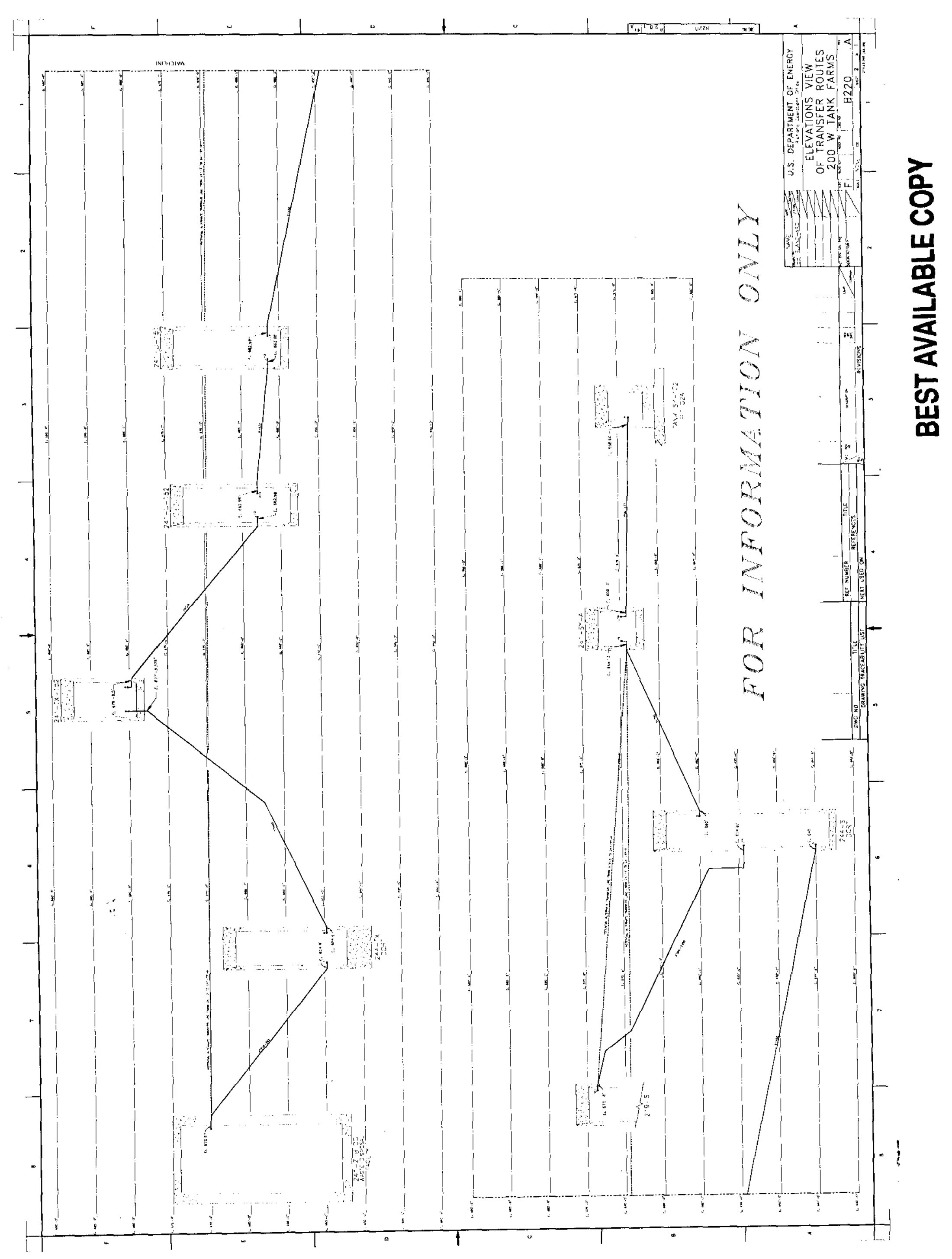

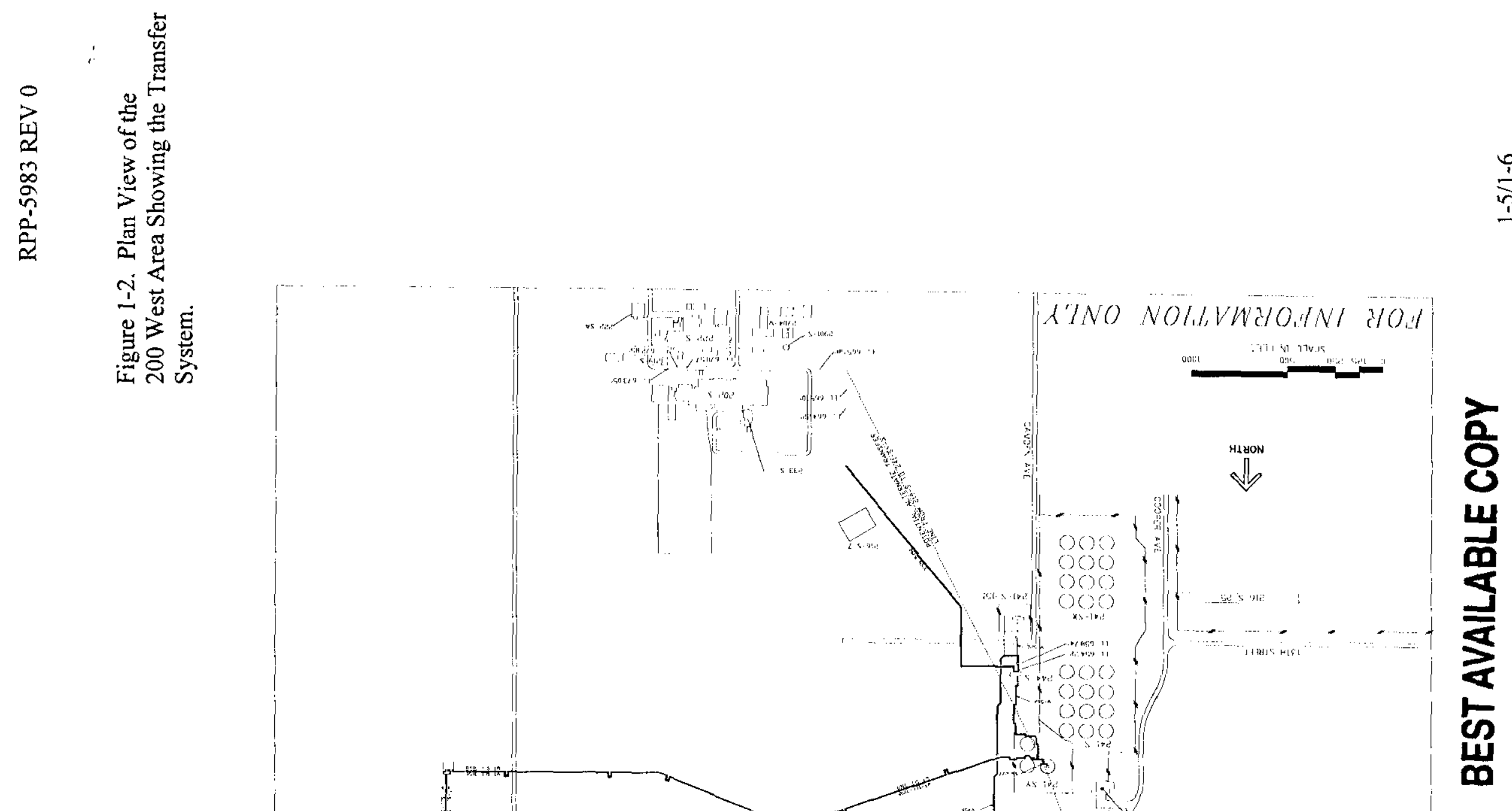


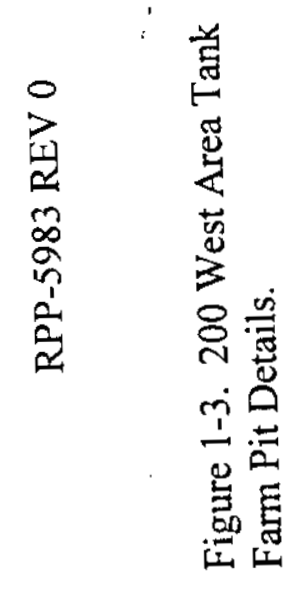
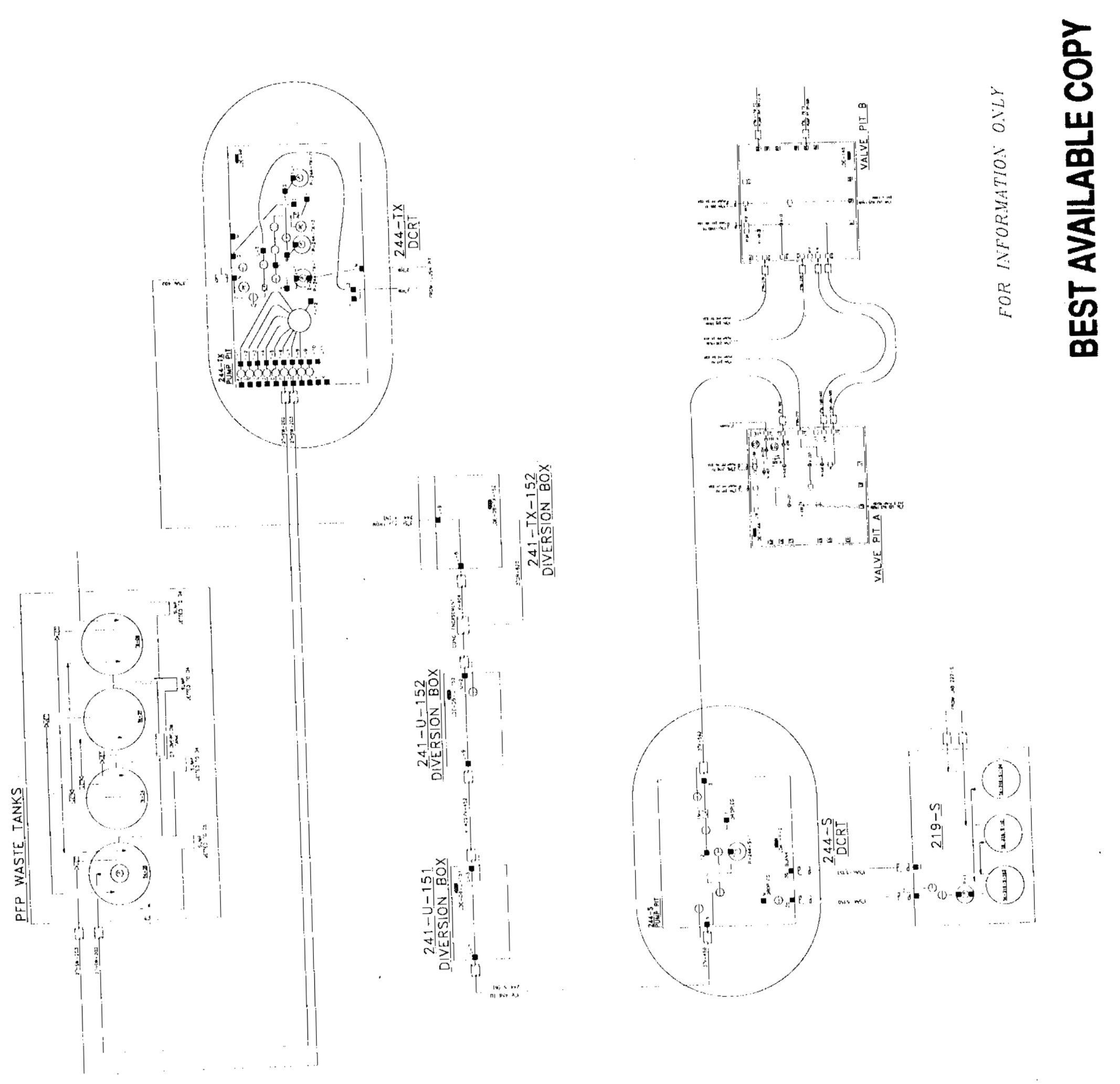


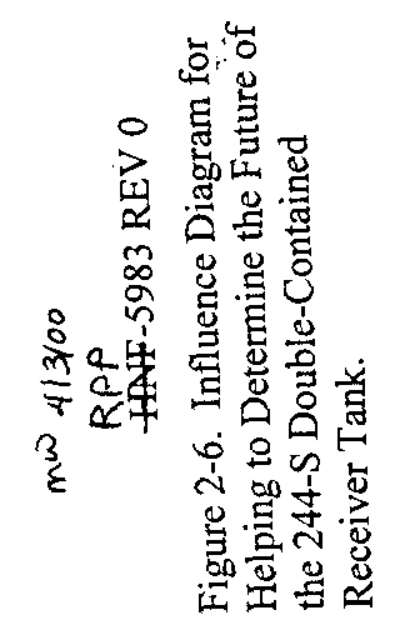

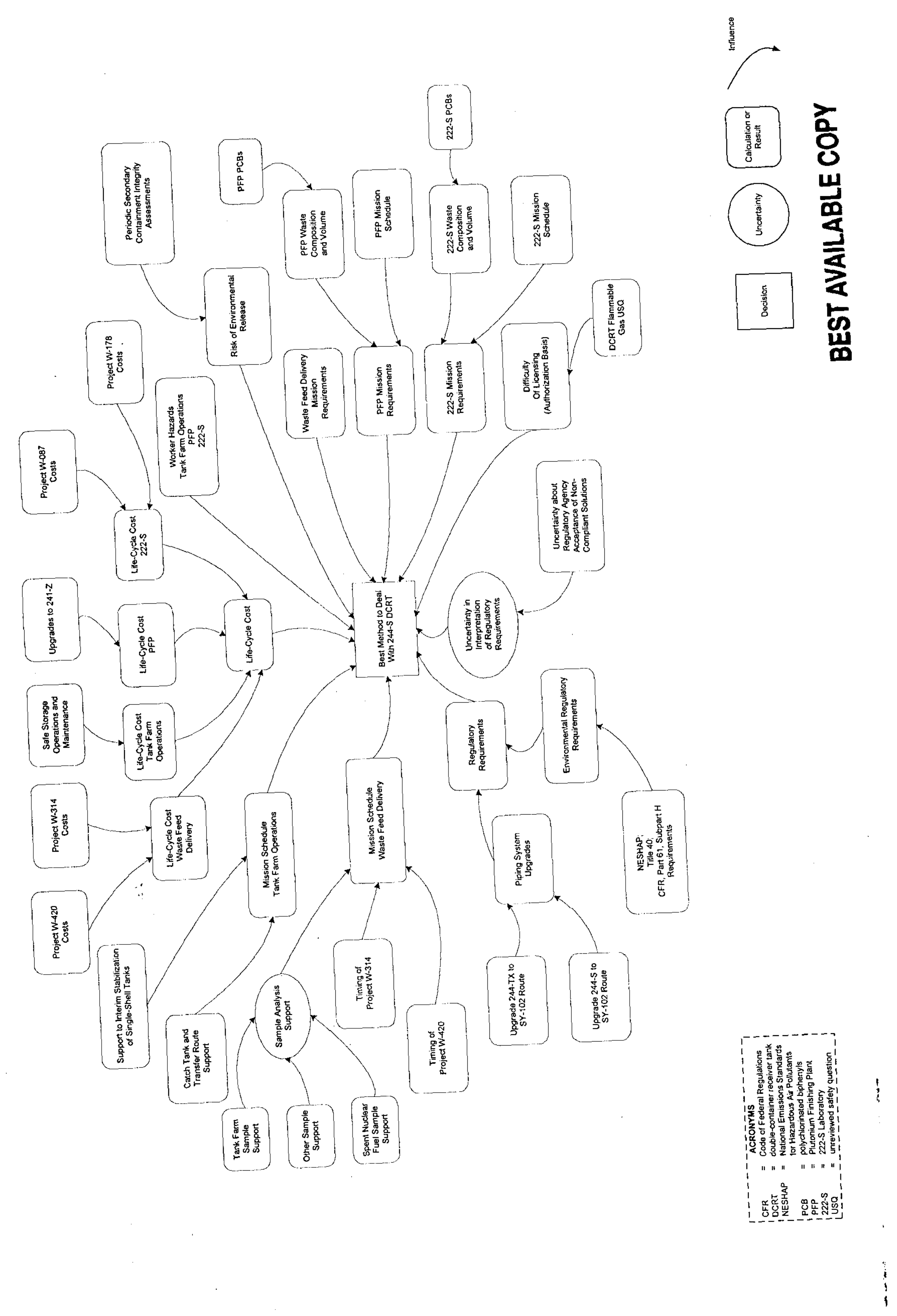




\subsection{DISCUSSION}

\subsection{TANK FARMS UPGRADES AND OPERATION COSTS}

A series of upgrades and normal operational activities that support the continued use of the 244-S DCRT transfer system are authorized by RPP-5044, River Protection Project FY 2000 Multi-Year Work Plan Summary. These upgrades and activities include:

- Project W-314 Workscope. The sum of $\$ 10$ million is allocated for the 244-S DCRT transfer system to install a primary vent duct flowmeter, a primary/annulus vent system, a leak detector, special protective coating in the pump pit; a nonfiltered duct jumper in the filter pit; primary tank instrumentation; monitoring and control upgrades, and electrical upgrades.

- Project W-420 Workscope. The sum of $\$ 700,000$ is reserved for the 244-S DCRT transfer system to demolish the existing stack, procure and install a new $15 \mathrm{~cm}(6-$ in.) stack (with a $10 \mathrm{~cm}$ [4-in.-] diameter discharge) and a new gaseous effluent-monitoring system to replace the existing stack continuous air-monitoring system.

- Normal Operations (i.e., safe storage operations and maintenance activities). An estimated $\$ 100,000$ per year is being expended, and likely will continue to be required, toward operational costs associated with the 244-S DCRT transfer system. Based on known cases of extending the use of a facility beyond its design life, these costs actually may increase if the 244-S DCRT transfer system is required to continue in service. Should the 244-S DCRT transfer system be needed to support PFP and 222-S in the future, it could be necessary to use the system for up to twice its original design life. Furthermore, the costs associated with assessing the integrity of the 244-S DCRT are included in this estimate. Integrity issues are identified in HNF-3608, 222-S Double Container Receiver Tank Facility Integrity Assessment Report.

In addition to these planned expenditures, other upgrades (beyond the present authorized plans) could be required to allow the continued use of the 244-S DCRT transfer system. Upgrades to piping systems, as noted in HNF-5254, DST Transfer System Piping Compliance, are postulated to be among these unfunded/unplanned upgrades. These upgrades would bring the piping transfer systems into compliance with the requirements contained in WAC 173-303-640, "Dangerous Waste Regulations: Tank Systems," by June 2005. These requirements include upgrades to secondary containment, improvements in leak-detection capabilities, and assurances of adequate failure prevention. However, no detailed cost estimates are available for completing this work.

Upon completing these upgrades/actions (both funded/planned and unfunded/unplanned), the 244-S DCRT transfer system is expected to meet the minimum acceptable standards for future use. Table 2-1 summarizes the minimum expected expenditures necessary to continue to allow the receipt of wastes through the 244-S DCRT transfer system. Expected completion dates for these planned/funded and unplanned/unfunded actions are included in Table 2-1. 
Table 2-1. Baseline Acceptable Standard-of-Use Scenario for the 244-S Double-Contained Receiver Tank Transfer System.

\begin{tabular}{|c|c|c|c|c|}
\hline Activity/Upgrade & By Whom & Cost $(\$)$ & Date & Reference \\
\hline $\begin{array}{l}\text { Installation of a primary vent duct } \\
\text { flowmeter, a primary/annulus vent } \\
\text { system, a leak detector, special } \\
\text { protective coating in the pump pit; } \\
\text { a nonfiltered duct jumper in the } \\
\text { filter pit; primary tank instruments; } \\
\text { monitoring and control upgrades, } \\
\text { and electrical upgrades. }\end{array}$ & $\begin{array}{l}\text { Currently } \\
\text { within the } \\
\text { scope and } \\
\text { funding of } \\
\text { Project W-314 }\end{array}$ & $\$ 10,000,000$ & 2004 & $\begin{array}{l}\text { HNF-5109, 1999, Phase } 2 \\
\text { Rebaseline Report for Tank } \\
\text { Farm Restoration and Safe } \\
\text { Operations Project } W-314, \\
\text { Rev. 0, Lockheed Martin } \\
\text { Hanford Corporation, } \\
\text { Richland, Washington. }\end{array}$ \\
\hline $\begin{array}{l}\text { Upgrade stack to meet } 40 \text { CFR } 61 \text {, } \\
\text { Subpart H. Specifically, remove } \\
\text { existing stack, install a new } 15 \mathrm{~cm} \\
\text { (6-in.-) stack (with } 10 \mathrm{~cm} \text { [4-in.-] } \\
\text { diameter discharge), and a new } \\
\text { gaseous effluent-monitoring } \\
\text { system. }\end{array}$ & $\begin{array}{l}\text { Currently } \\
\text { within the } \\
\text { scope and } \\
\text { funding of } \\
\text { Project W-420. }\end{array}$ & $\$ 700,000$ & 2000 & $\begin{array}{l}\text { HNF-SD-W420-CDR-001, } \\
\text { 1998, Project W-420 Stack } \\
\text { Monitoring System Upgrades } \\
\text { Conceptual Design Report, } \\
\text { Rev. 1, Numatec Hanford } \\
\text { Corporation, Richland, } \\
\text { Washington. }\end{array}$ \\
\hline $\begin{array}{l}\text { Upgrade transfer lines from the } \\
241-Z \text { and } 219-S \text { Waste Handling } \\
\text { Facilities to Tank } 241-S Y-102 \text { to } \\
\text { maintain RCRA compliance. }\end{array}$ & $\begin{array}{l}\text { Currently } \\
\text { unplanned/ } \\
\text { unfunded } \\
\text { scope }\end{array}$ & $\$ 5,000,000+*$ & $\begin{array}{l}\text { Commit- } \\
\text { ment } \\
\text { date with } \\
\text { WDOE } \\
\text { is } 2005 \text {. }\end{array}$ & $\begin{array}{l}\text { HNF-5254, 2000, DST } \\
\text { Transfer System Piping } \\
\text { Compliance, Rev. 0, } \\
\text { CH2M HILL Hanford Group, } \\
\text { Inc., Richland, Washington. }\end{array}$ \\
\hline $\begin{array}{l}\text { Normal safe storage operations and } \\
\text { maintenance. This includes } \\
\text { operators, engineers, and } \\
\text { maintenance crafts staff performing } \\
\text { surveillance and modifications } \\
\text { necessary for day-to-day upkeep of } \\
\text { the facility. }\end{array}$ & $\begin{array}{l}\text { Tank Farm } \\
\text { Safe Storage } \\
\text { Operations } \\
\text { Program } \\
\text { (currently } \\
\text { under TW03 } \\
\text { funding) }\end{array}$ & $\$ 2,000,000$ & $\begin{array}{l}2000- \\
2020\end{array}$ & $\begin{array}{l}\$ 100,000 \text { per year with no } \\
\text { escalation (see Appendix A). }\end{array}$ \\
\hline \multicolumn{2}{|l|}{ Total Cost $=$} & $\$ 17,700,000+$ & & \\
\hline
\end{tabular}

*Estimate based on potential line lengths and similar projects that have been completed recently. $\mathrm{CFR}=$ Code of Federal Regulations

RCRA = Resource Conservation and Recovery Act of 1976, 42 USC 6901.

WDOE $=$ Washington State Department of Ecology.

40 CFR 61, "National Emission Standards for Hazardous Air Pollutants," Subpart H, "National Emissions Standards for Emissions of Radionuclides other than Radon from Department of Energy Facilities," Code of Federal Regulations, as amended. 


\subsection{OPERATIONAL WASTE VOLUME PROJECTIONS}

Periodic operational waste volume projections (OWVP) are made to plan for the receipt of customer wastes. These OWVPs help with the analysis of DST space needs. Waste-generation data (specifically, waste volumes and compositions) have been published in reports such as HNF-SD-WM-ER-029, Operational Waste Volume Projection. Revision 25 of HNF-SD-WM-ER-029 is the current governing authority for future projections of 222-S and PFP wastes. HNF-SD-WM-ER-029 is expected to be updated during fiscal year 2000. Figure 2-1 shows the actual cumulative waste volume generations from 222-S and PFP realized from 1989 to date. The data in Table 2-2 and Figure 2-2 show that in most years 222-S transferred far less waste to the tank farms than projected. The data presented in Figure 2-3 show that cumulative historical transfer volumes for PFP are approaching the projected terminal cleanout volume. Table 2-2, Figure 2-1, Figure 2-2, and Figure 2-3 are based on current and former versions of HNF-SD-WM-ER-029.

Table 2-2. 222-S Laboratory Waste Generation, Projections versus Actuals.*

\begin{tabular}{|c|c|c|}
\hline Fiscal Year & $\begin{array}{c}\text { Projected Monthly } \\
\text { Volume, kgal }\end{array}$ & $\begin{array}{c}\text { Actual Average } \\
\text { Monthly Volume, kgal }\end{array}$ \\
\hline 1990 & 4.00 & 2.18 \\
\hline 1991 & 5.00 & 3.75 \\
\hline 1992 & 4.00 & 2.30 \\
\hline 1993 & 5.00 & 0.83 \\
\hline 1994 & 5.00 & 1.58 \\
\hline 1995 & 1.90 & 1.80 \\
\hline 1996 & 1.90 & 2.30 \\
\hline 1997 & 2.50 & 0.60 \\
\hline 1998 & 1.70 & 0.90 \\
\hline 1999 & 1.30 & 0.20 \\
\hline 2000 & 1.12 & not applicable \\
\hline
\end{tabular}

NOTE: $1 \mathrm{~L}=0.264 \mathrm{gal}$ 


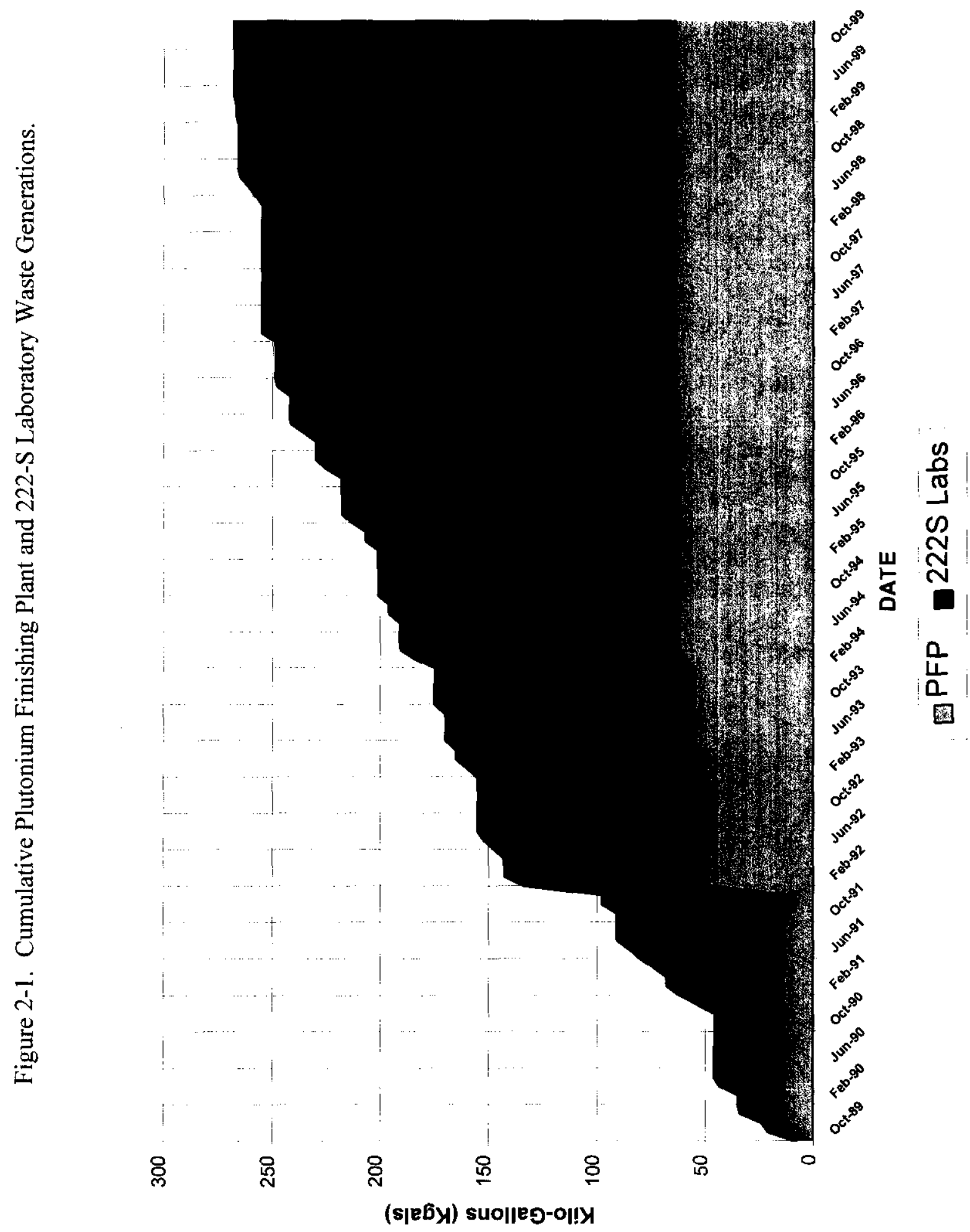


Figure 2-2. 222-S Laboratory Waste Generations, Projections versus Actual.

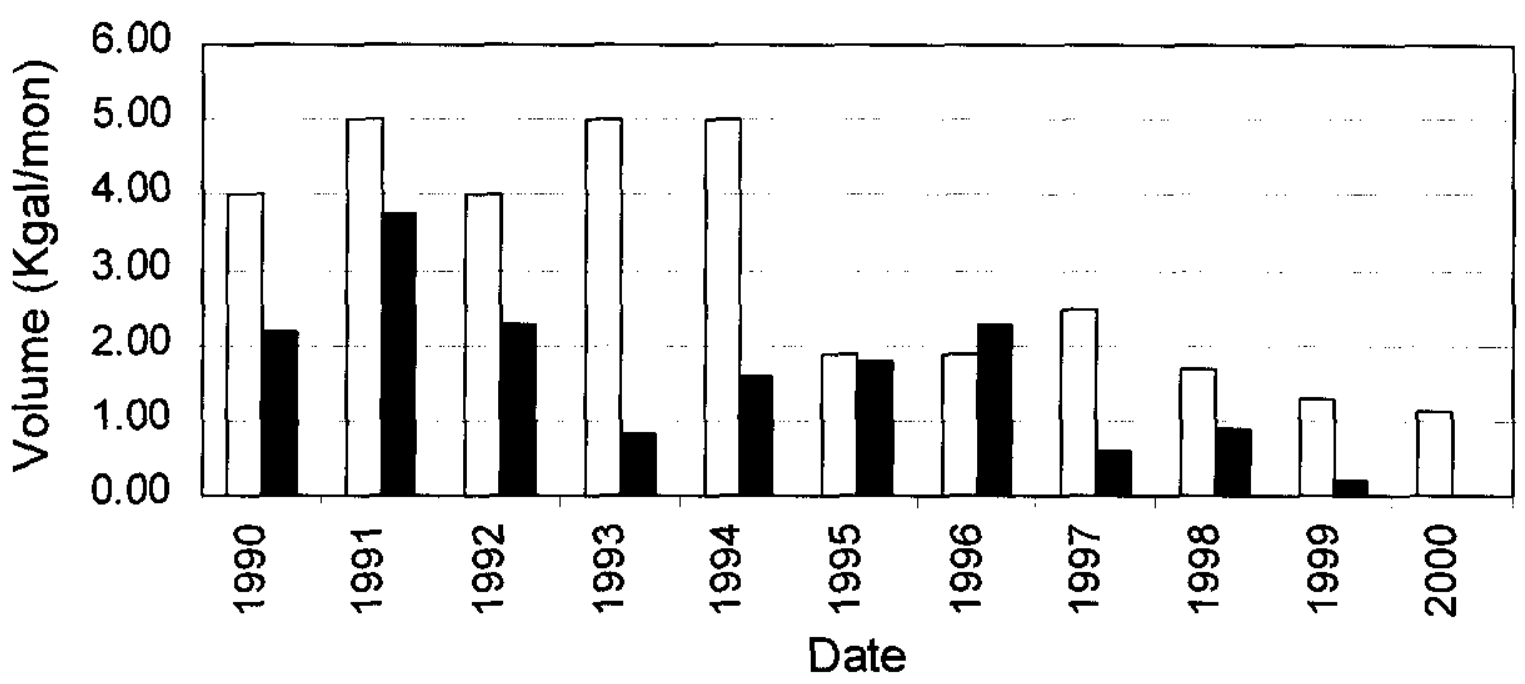

$\square$ Projections Actuals

Figure 2-3. Plutonium Finishing Plant Waste Generations, Projection versus Actual.

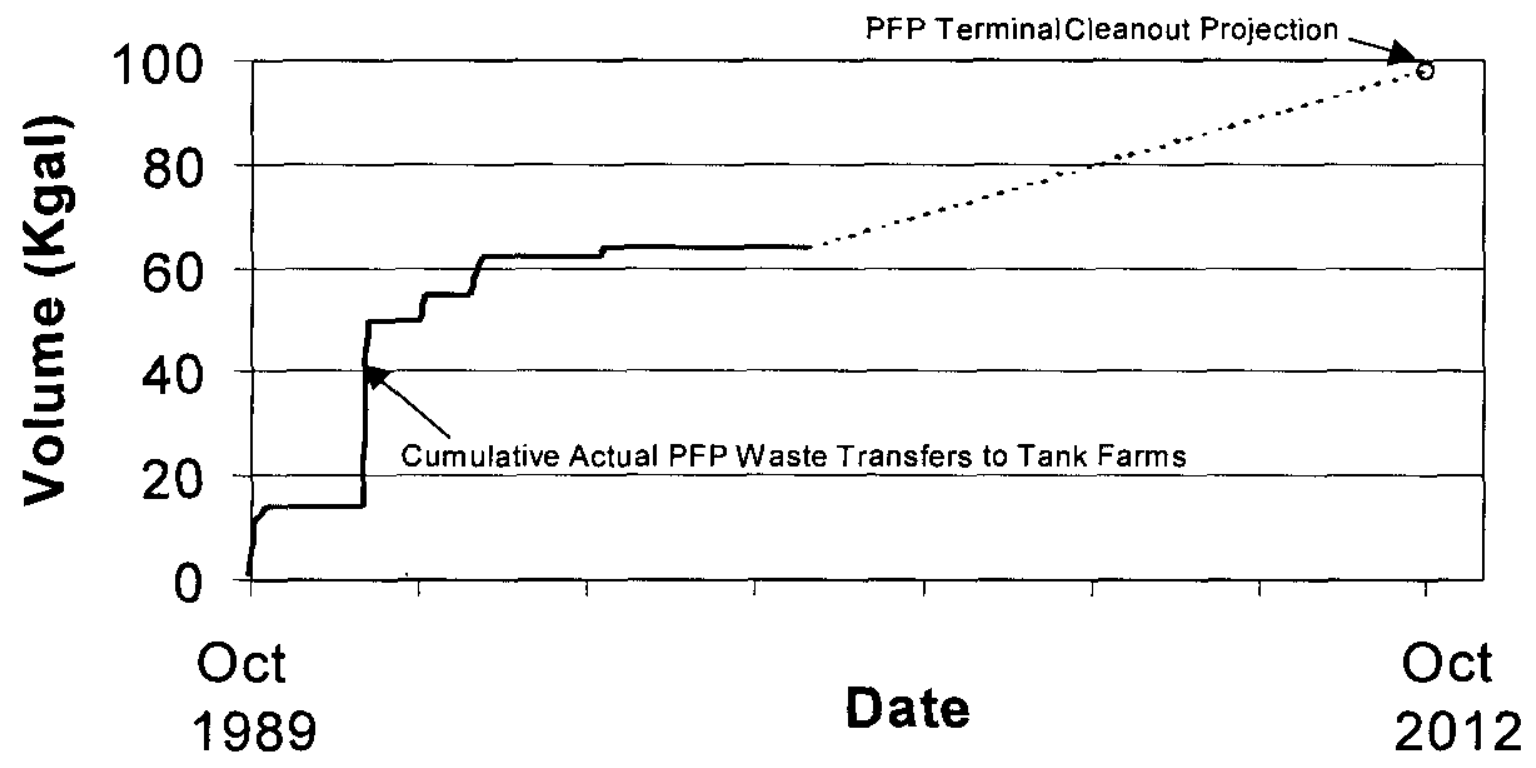


Based on the current projections of 222-S and PFP waste generation, the compositional data presented in Tables 2-3 and 2-4 are the understood baseline characteristics for these two waste streams. The values for the constituents shown in Tables 2-3 and 2-4 are relatively small in comparison to the larger masses associated with the inventories contained in the DSTs being managed in a safe storage mode. ${ }^{1}$

As waste is generated at the various facilities, it is collected, managed, and subsequently transferred to the tank farms. The interface between 222-S and the tank farms is described in HNF-4483, Interface Control Document Between the Tank Farm System and 222-S Laboratory. The interface between PFP and the tank farms is described in HNF-4486, Interface Control Document Between the Double-Shell Tanks (DST) System and the Plutonium Finishing Plant (PFP). The methodology employed by 222-S and PFP to prepare wastes for transmittal to the tank farms is described in the following sections.

\section{$2.3 \quad 222-S$ LABORATORY}

All waste in the S Plant system is generated in 222-S. Hot sink drains and hot tunnel sump wastes are jetted or "slurped" to the 219-S Waste Handling Facility through stainless steel lines. A flowchart of the 222-S liquid waste-handling scheme is shown in Figure 2-4.

The 219-S Waste Handling Facility consists of two cells (A and B) that contain Tanks 219-S-101, -102, -103, and -104. Tank 219-S-103 has been isolated and abandoned in place. The three active tanks (219-S-101, -102, and -104) are vented by an electrical exhaust fan through a demister (known as Tank 219-S-105) and a high-efficiency particulate air filter (HEPA) to the atmosphere via the 296-S-16 stack.

Waste transfers from 222-S are routed to either Tank 219-S-101 or -104. Wastes from Tanks 219-S-101 and -104 then are jetted to Tank 219-S-102 for treatment. The transfer pumps and lines are flushed after both internal transfers (i.e., within 222-S and the 219-S Waste Handling Facility) and external transfers (i.e., routed to the tank farms). A new transfer line (installed as part of Project W-087) to 200 West Area tank farms was placed into service in December 1997. This line allows for transfers from tanks in the 219-S Waste Handling Facility to the 244-S DCRT transfer systems.

\footnotetext{
'An excess of 72 million liters (19 million gallons) of waste is stored in the existing DST system, which comprises 28 DSTs.
} 
Table 2-3. Projected Customer Waste Volumes and Compositions for the 200 West Area Tank Farms.

\begin{tabular}{|c|c|c|}
\hline & 222-S Laboratory & Reference \\
\hline 254 & kgal of waste from 2000 to 2018 at $\sim 12 \mathrm{kgal} / \mathrm{yr}$ & 1 \\
\hline 98.04 & wt $\%$ water $(<0.5$ wt $\%$ solids $)$ & 2,4 \\
\hline 0.21 & $\mathrm{wt} \% \mathrm{NaCl}$ & 2 \\
\hline 1.3 & $\mathrm{wt} \% \mathrm{NaNO}_{3}$ & 2 \\
\hline 0.17 & $\mathrm{wt} \% \mathrm{NaNO}_{2}$ & 2 \\
\hline $0 . \overline{28}$ & $\mathrm{wt} \% \mathrm{NaOH}$ & 2 \\
\hline 206 & $\mu \mathrm{Ci} / \mathrm{L}$ Total Beta & 2 \\
\hline 2.1 & $\mu \mathrm{Ci} / \mathrm{L}$ Alpha Total & 2 \\
\hline 102 & $\mu \mathrm{Ci} / \mathrm{L}{ }^{137} \mathrm{Cs}$ & 2 \\
\hline 6.63 & $\mu \mathrm{Ci} / \mathrm{L}{ }^{129} \mathrm{I}$ & 2 \\
\hline 5.45 & $\mu \mathrm{Ci} / \mathrm{L} \mathrm{Pm}$ & 2 \\
\hline 0.313 & $\mu \mathrm{Ci} / \mathrm{L}^{239 / 240} \mathrm{Pu}$ & 2 \\
\hline 63.5 & $\mu \mathrm{Ci} / \mathrm{L}^{89 / 90} \mathrm{Sr}$ & 2 \\
\hline 0.148 & $\mu \mathrm{Ci} / \mathrm{L}{ }^{99} \mathrm{Tc} 99$ & 2 \\
\hline 0.013 & $\mathrm{~g} / \mathrm{L} \mathrm{U}$ & 2 \\
\hline 0.963 & $\mu \mathrm{Ci} / \mathrm{L}^{241} \mathrm{Am}$ & 2 \\
\hline 0.00171 & $\mu \mathrm{Ci} / \mathrm{mL}^{3} \mathrm{H}$ & 2 \\
\hline 0.00103 & $\mu \mathrm{Ci} / \mathrm{mL}^{\mathrm{TA}} \mathrm{C}$ & 2 \\
\hline & Plutoniun Finishing Plant & Reference \\
\hline 32 & $\mathrm{kgal}$ of waste from 2000 to $2013^{*}$ ranging from 1 to $10 \mathrm{kgal} / \mathrm{yr}$ & 1 \\
\hline 3.4 & $\mathrm{~mol} / \mathrm{L} \mathrm{Na}^{+}$ & 3 \\
\hline 1.5 & $\mathrm{~mol} / \mathrm{L} \mathrm{OH}-$ & 3 \\
\hline 1.6 & $\mathrm{~mol} / \mathrm{L} \mathrm{NO}_{3}^{-}$ & 3 \\
\hline 0.28 & $\mathrm{~mol} / \mathrm{L} \mathrm{NO}_{2}^{-}$ & 3 \\
\hline not reported & $\mathrm{mol} / \mathrm{L} \mathrm{Fe}{ }^{2+}$ & $\widehat{N A}$ \\
\hline 0.00731 & $\mathrm{~g} / \mathrm{L} \mathrm{Pu}$ & 3 \\
\hline 0.0000307 & $\mathrm{~g} / \mathrm{L} \mathrm{Am}$ & 3 \\
\hline$<0.00001$ & $\mathrm{~g} / \mathrm{L} \mathrm{U}$ & 3 \\
\hline 3 & vol\% solids & 3 \\
\hline$\sqrt{404}$ & (X) & 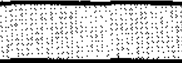 \\
\hline \multicolumn{3}{|c|}{$\begin{array}{l}\text { HNF-SD-WM-ER-029, 1999, Operational Waste Volume Projection, Rev. 25, Lockheed Martin Hanford Corporation, } \\
\text { Richland, Washington }\end{array}$} \\
\hline \multicolumn{3}{|c|}{$\begin{array}{l}\text { Westcott, J. L., 1998, "Update to S-Plant and Waste Sampling and Characterization Facilities Waste Volume Projection } \\
\text { Assumptions," (Letter \#WMH-9860419 to J. N. Strode, Lockheed Martin Hanford Corporation with Attachment "222-S } \\
\text { Laboratory Facility Description," December 30), Waste Management Federal Services, Richland, Washington. }\end{array}$} \\
\hline \multicolumn{3}{|c|}{$\begin{array}{l}\text { Hirzel, D. R., 1999, "Plutonium Finishing Plant Waste Volume Projection for the Period FY 1999-2028" (Memo } \\
\text { \#15530-99-DRH-002 to J. N. Strode, Lockheed Martin Hanford Corporation, January 6), B\&W Hanford Company, } \\
\text { Richland, Washington. }\end{array}$} \\
\hline \multicolumn{3}{|c|}{$\begin{array}{l}\text { Fowler, K. D., 1998, "Waste Compatibility Assessment of 222-S Laboratory Waste (222-S-98-3) with Tank 241-SY-102 } \\
\text { Waste via Double Contained Receiver Tank 244-S for Project W-178 Hydrolancing" (Interoffice Memo \#7A150-98-037 } \\
\text { with attachment to R. E. Larson, August 26), Lockheed Martin Hanford Corporation, Richland, Washington. }\end{array}$} \\
\hline
\end{tabular}


Table 2-4. Nominal Customer Waste Compositions Converted to Common Units.

\begin{tabular}{|c|c|c|c|}
\hline Analyte & $\begin{array}{c}\text { Calculated Value for } \\
222-S \text { Laboratory }\end{array}$ & $\begin{array}{c}\text { Calculated Value for Plutonium } \\
\text { Finishing Plant }\end{array}$ & New Units \\
\hline $\mathrm{H}_{2} \mathrm{O}$ & $9.90 \mathrm{E}+05$ & not applicable & $\mu \mathrm{g} / \mathrm{mL}$ \\
\hline $\mathrm{Cl}$ & $1.29 \mathrm{E}+03$ & not applicable & $\mu \mathrm{g} / \mathrm{mL}$ \\
\hline $\mathrm{NO}_{3}$ & $9.58 \mathrm{E}+03$ & $1.02 \mathrm{E}+05$ & $\mu \mathrm{g} / \mathrm{mL}$ \\
\hline $\mathrm{NO}_{2}$ & $1.14 \mathrm{E}+03$ & $1.30 \mathrm{E}+04$ & $\mu \mathrm{g} / \mathrm{mL}$ \\
\hline $\mathrm{OH}$ & $1.20 \mathrm{E}+03$ & $2.54 \mathrm{E}+04$ & $\mu \mathrm{g} / \mathrm{mL}$ \\
\hline $\mathrm{Fe}$ & not applicable & not reported & $\mu \mathrm{g} / \mathrm{mL}$ \\
\hline $\mathrm{Na}$ & $6.58 \mathrm{E}+03$ & $7.80 \mathrm{E}+04$ & $\mu \mathrm{g} / \mathrm{mL}$ \\
\hline${ }^{137} \mathrm{Cs}$ & $1.17 \mathrm{E}-03$ & not applicable & $\mu \mathrm{g} / \mathrm{mL}$ \\
\hline${ }^{129} \mathrm{I}$ & $3.76 \mathrm{E}-01$ & not applicable & $\mu \mathrm{g} / \mathrm{mL}$ \\
\hline${ }^{239} \mathrm{Pu}$ & $4.03 \mathrm{E}-03$ & $6.85 \mathrm{E}+00$ & $\mu \mathrm{g} / \mathrm{mL}$ \\
\hline${ }^{240} \mathrm{Pu}$ & $2.75 \mathrm{E}-04$ & $4.67 \mathrm{E}-01$ & $\mu \mathrm{g} / \mathrm{mL}$ \\
\hline${ }^{90} \mathrm{Sr}$ & $4.66 \mathrm{E}-04$ & not applicable & $\mu \mathrm{g} / \mathrm{mL}$ \\
\hline${ }^{99} \mathrm{Tc}$ & $8.73 \mathrm{E}-03$ & not applicable & $\mu \mathrm{g} / \mathrm{mL}$ \\
\hline $\mathrm{U}$ & $1.30 \mathrm{E}+01$ & $1.00 \mathrm{E}-02$ & $\mu \mathrm{g} / \mathrm{mL}$ \\
\hline${ }^{241} \mathrm{Am}$ & $2.81 \mathrm{E}-04$ & $3.07 \mathrm{E}-02$ & $\mu \mathrm{g} / \mathrm{mL}$ \\
\hline${ }^{3} \mathrm{H}$ & $1.77 \mathrm{E}-07$ & not applicable & $\mu \mathrm{g} / \mathrm{mL}$ \\
\hline${ }^{14} \mathrm{C}$ & $2.31 \mathrm{E}-04$ & not applicable & $\mu \mathrm{g} / \mathrm{mL}$ \\
\hline Solids & not applicable & 3 & $\mathrm{vol} \%$ \\
\hline
\end{tabular}

Figure 2-4. 222-S Laboratory Liquid-Waste-Handling Scheme.

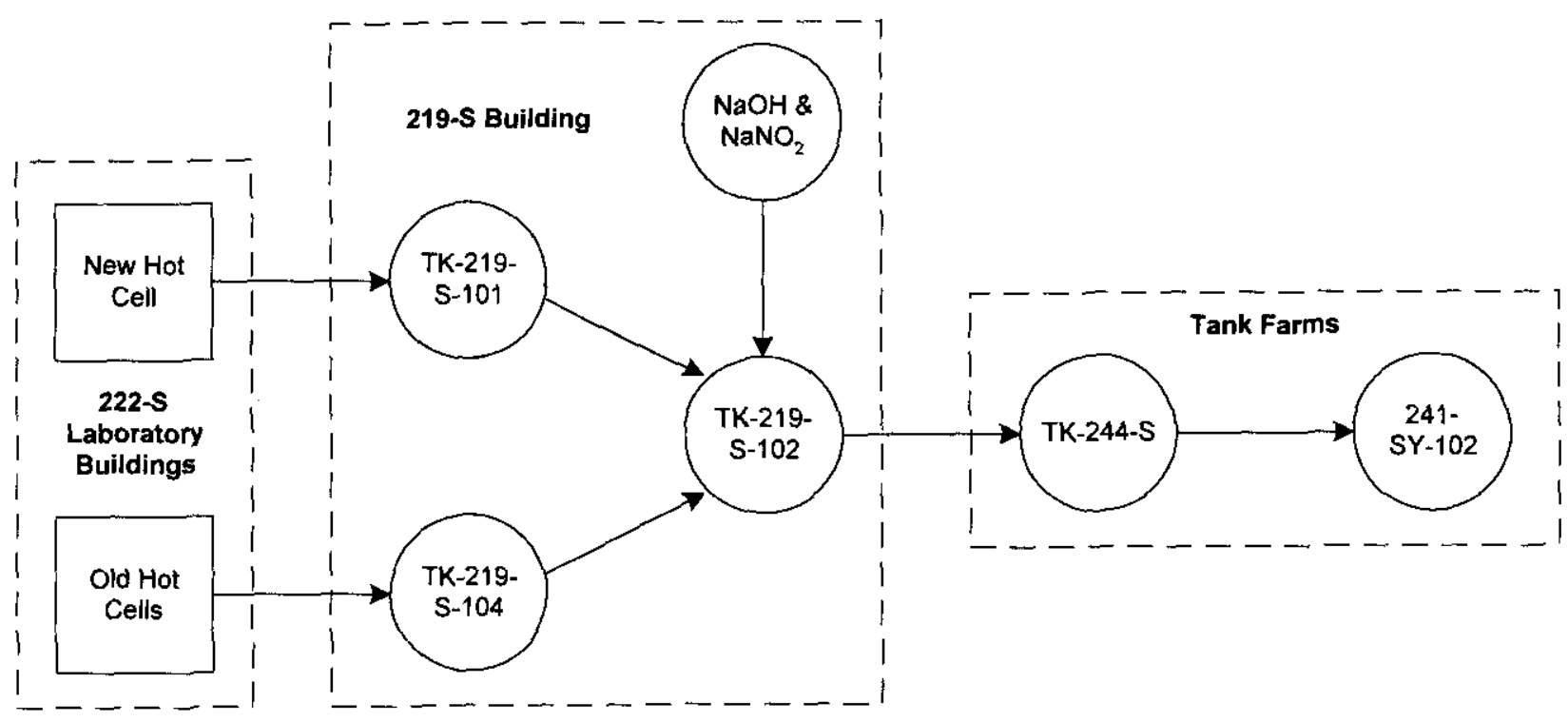


Project W-178 was initiated shortly after the start of Project W-087 to modify the pipe and tank configurations internal to 222-S and the 219-S Waste Handling Facility. Since the completion of Project W-178, wastes generated from Room 11A in 222-S are routed to Tank 219-S-101. Other 222-S wastes generated from laboratory operations in the hot cells (1A, 1E-1, 1E-2, and 1F), the inductively coupled plasma spectrometer, the atomic spectrophotometer (Room $1 \mathrm{~K}$ drain), slurping hoods, acid decontamination sinks, and hot tunnel sumps are routed to Tank 219-S-104.

Waste batches in Tanks 219-S-101 and -104 are transferred to Tank 219-S-102. The waste is sampled and analyzed for chemical content and radioactivity in Tank 219-S-102 and treated with $\mathrm{NaOH}$ and $\mathrm{NaNO}_{2}$. Waste batches of approximately $11,000 \mathrm{~L}(3,000$ gal) each are subsequently transferred from Tank 219-S-102 to the 244-S DCRT transfer system.

\subsection{PLUTONIUM FINISHING PLANT}

All waste in the PFP system is generated in a group of facilities in the 200 West Area. These facilities support the operations for the following:

- Stabilization of plutonium metal by muffle furnace calcination

- Immobilization of sand, slag, and crucible residues for disposal

- Application of the Direct Denitration Vertical Calciner

- Shipping, receiving, and storage of special nuclear materials

- Functioning of the Analytical Laboratory and the Plutonium Process Support Laboratory

- Treatment and handling of liquid wastes destined for tank farms and the Treated Effluent Disposal Facility.

Wastes from the various facilities that constitute PFP are routed to the $241-Z$ Waste Handling Facility via stainless steel lines. A flowchart showing the handling process at the $241-\mathrm{Z}$ Waste Handling Facility is shown in Figure 2-5.

The 241-Z facility consists of five cells that contain five tanks (D-4 through D-8). Tank D-6 is inactive and has been isolated and abandoned in place. Of the four remaining active tanks, only two tanks (D-8 and D-5) are used to complete transfers to the tank farms. The other two tanks (D-4 and D-7) are used for overflow protection of the active waste tanks (D-5 and D-8). 
Figure 2-5. Plutonium Finishing Plant Liquid-Waste-Handling Scheme.

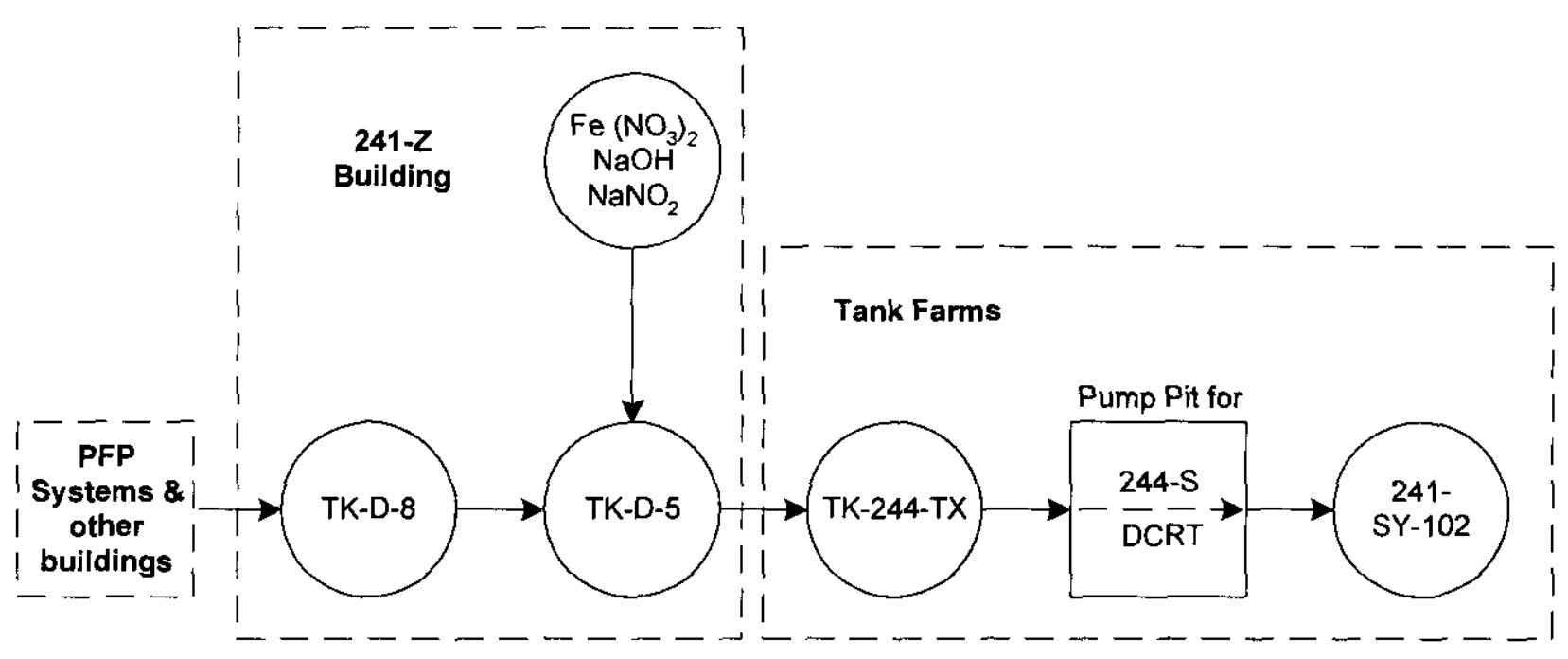

All PFP wastes are routed to the 241-Z Waste Handling Facility through one pipe. (At one time, there were as many as five different pipes into the $241-Z$ Waste Handling Facility from the remainder of the plant. Because of process changes and leaking pipes and tanks, these pipes were eventually grouped to form this one compliant line in use today.) Wastes are collected in Tank D-8; when a batch is ready, it is jetted to Tank D-5 where it can be mixed, sampled, and neutralized (as necessary). ${ }^{2}$ After the prescribed processes and procedures are satisfied, a waste batch is configured for routing to the tank farms (currently the 244-TX DCRT).

\subsection{INFLUENCES}

During initial meetings (Sederburg 1999) held to define this problem, a number of issues and items were identified that may influence any potential decisions about the 244-S DCRT transfer system. The following issues and items were identified during these initial meetings.

1. Does the open unreviewed safety question (Consolidation of Flammable Gas/Slurry Growth Unreviewed Safety Question Issue [Serrano and Schofield, 1996)] regarding flammable gas controls in all DCRTs need further resolution before proceeding with any specific upgrades of projects or plans for the 244-S DCRT?

2. Is it necessary for the 244-S DCRT transfer system to continue providing catch tank support for waste transfers from 244-TX DCRT to Tank 241-SY-102? (These waste transfers primarily are from PFP. Other waste, including waste from S-304 and UX-302-A, may be transferred along this route in the future, but no transfers are presently planned.) Are other, more favorable transfer routes available that would not require the 244-S DCRT transfer

\footnotetext{
2 The agitator that mixes the waste is assumed to be operating continuously.
} 
system to serve as a catch tank for encasement drainage or line drainage during jumper maintenance?

3. By what time does Project W-314 need to make decisions to ensure their input properly influences their scope of work?

4. What effects will the analyses presented in HNF-5254 have on future decisions about the 244-S DCRT transfer system?

5. What are the influences of the needs of $222-\mathrm{S}$ on decisions about the future of the 244-S DCRT transfer system?

6. What are the influences of the needs of PFP on decisions about the future of the 244-S DCRT transfer system?

7. What interaction with Project W-420 is involved/required?

8. Are there any long-term effects to be realized from the recent discovery of polychlorinated biphenyl at the 219-S Waste Receiving Facility? Are there any other types of wastecompatibility issues that need to be considered?

9. Have the recommendations in HNF-3608, which are encompassed in Table 2-1, been considered?

Input from several different organizations will be required to disposition these issues and items appropriately. A preliminary summary of the various influences on this problem is depicted in Figure 2-6. Table 2-5 shows a proposed team arrangement that could be used to reach a solution amenable to all concerned parties.

\footnotetext{
${ }^{3} 222-S$ and PFP are proceeding under the assumption that they can "clean" their tanks and systems and resume sending waste to the tank farms.
} 
Table 2-5. Potential Task Team for the 244-S Double-Contained Receiver Tank Transfer System.

\begin{tabular}{|c|c|c|}
\hline Representing & Representative & Role \\
\hline Retrieval Engineering & Pete Sederburg & Lead \\
\hline Retrieval Engineering & Becky Johnson & Editor \\
\hline 200 West Area Operations & Doug Larsen & \multirow{4}{*}{ Member } \\
\hline Plutonium Finishing Plant & Paul Roege & \\
\hline 222-S Laboratory & Steve Brey & \\
\hline All Projects & John W. Bailey & \\
\hline Retrieval Engineering & Brian Blanchard & \multirow{5}{*}{ Assistant } \\
\hline Process Engineering & Ken Fowler & \\
\hline Retrieval Operations & Olaf Rasmussen & \\
\hline Plutonium Finishing Plant & Dave Hirzel & \\
\hline 222-S Laboratory & Larry Goodwin & \\
\hline Retrieval Engineering/Project W-314 & John Galbraith & \multirow{14}{*}{$\begin{array}{l}\text { Advisor, } \\
\text { Source of } \\
\text { Information }\end{array}$} \\
\hline Equipment Engineering & Ed Fredenberg & \\
\hline Single-Shell Tank Plant Engineering & Jeff Doeler & \\
\hline Tank Farm Field Operations & Dan Niebuhr & \\
\hline $\begin{array}{l}\text { Single-Shell Tank Retrieval System Definition \& } \\
\text { Implementation }\end{array}$ & Bill Stokes & \\
\hline Single-Shell Tank Interim Stabilization & Dave Saueressig & \\
\hline Characterization & George Stanton & \\
\hline Nuclear Safety and Licensing & Tom Goetz & \\
\hline Environmental & Phil Miller & \\
\hline Environmental & Brad Erlandson & \\
\hline Plutonium Finishing Plant & Ted Venetz & \\
\hline Plutonium Finishing Plant & Andy Westra & \\
\hline LR-56 Truck Cognizant Engineer & Todd Brown & \\
\hline Project W-420 & Keith Carpenter & \\
\hline Retrieval Engineering & Pete Owen & \multirow{3}{*}{ Peer Reviewer } \\
\hline Single-Shell Tank Plant Engineering & Paul Kison & \\
\hline Environmental & Ross Potter & \\
\hline
\end{tabular}




\subsection{POTENTIAL ANSWERS}

In an effort to solve the problem and associated issues with the 244-S DCRT transfer system, six options initially were considered for each of the two affected customers (222-S and PFP). A tabular development of these options and the involvement of the two affected customers was used to combine the options and develop a list of alternatives that should be considered further. Table 3-1 shows how these alternatives were developed and prescreened. Based on this process, eight potential answers were determined viable for further analysis in a 244-S DCRT alternatives generation and analysis. The resulting alternatives to be considered are briefly described below.

1. Upgrade the 244-S DCRT transfer system as planned, thereby allowing 222-S and PFP to continue transferring wastes using the same methods used now.

2. Modify the existing set of transfer lines such that the 244-S DCRT transfer system is bypassed and can be decommissioned. This alternative would have little to no effect on 222-S and PFP because the tank farms would continue to receive their wastes. However, modifying these transfer lines to eliminate the need for the 244-S DCRT transfer system possibly could allow tank farms to redirect currently planned expenditures.

3. Modify the present piping system for the 222-S transfers, thereby bypassing the 244-S DCRT transfer system (as in Alternative 2), but redirect and route PFP wastes into the tank farms via truck (probably to the 204-AR Facility in the 200 East Area). Decommission the 244-S DCRT transfer system.

4. Truck 222-S waste to a 204-AR-type facility and reroute PFP wastes directly to Tank 241-SY-102. Decommission the 244-S DCRT transfer system.

5. Truck 222-S and PFP wastes to a 204-AR-type facility. Decommission the 244-S DCRT transfer system.

6. Treat 222-S and PFP wastes at their respective sources. Decommission the 244-S DCRT transfer system.

7. Construct a new facility to replace the $244-\mathrm{S}$ DCRT transfer system. This alternative would have little to no effect on 222-S and PFP.

8. Do nothing. 


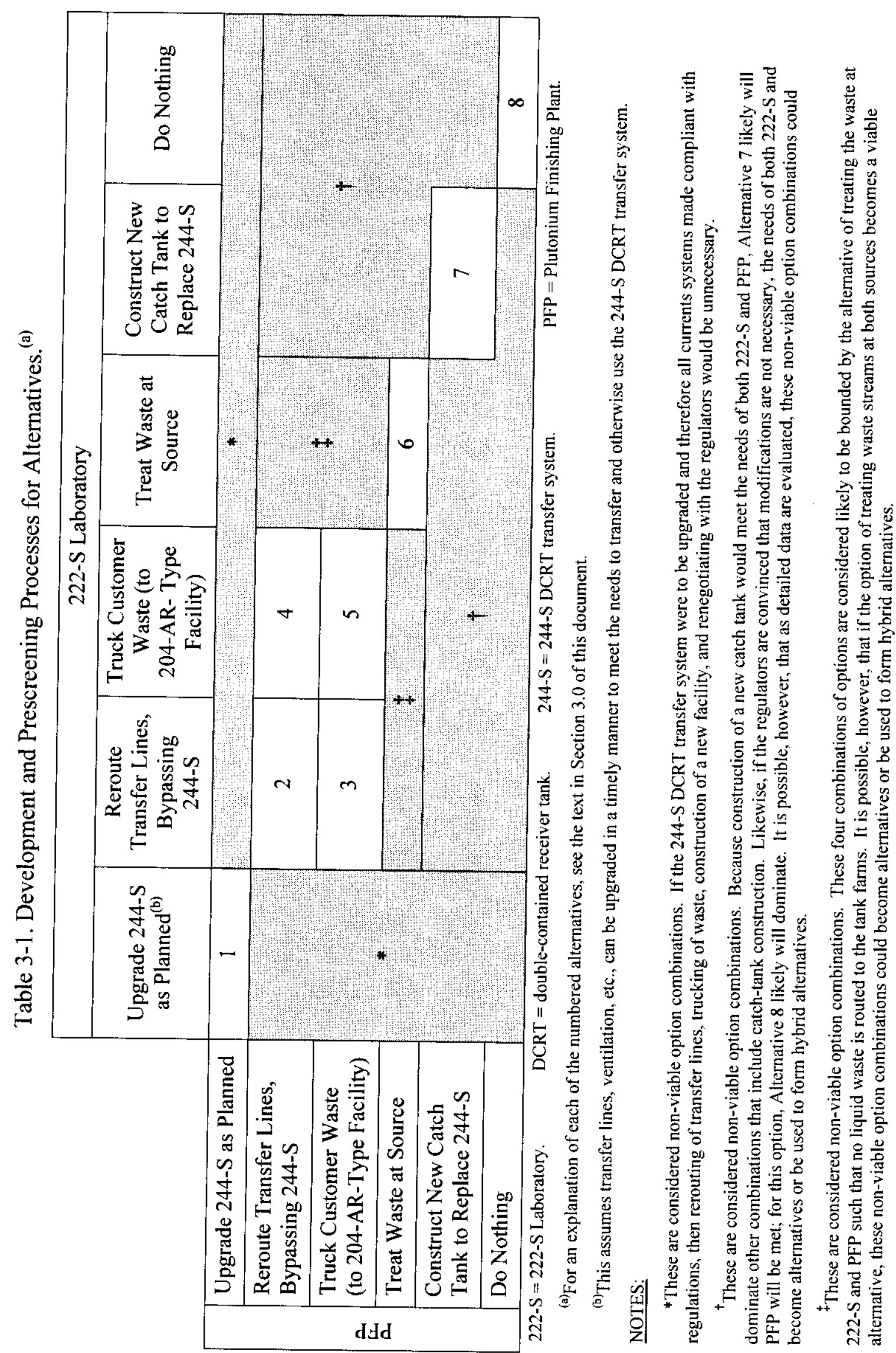


RPP-5983 REV 0

\subsection{REFERENCES}

40 CFR 61, "National Emission Standards for Hazardous Air Pollutants," Subpart H, "National Emissions Standards for Emissions of Radionuclides other than Radon from Department of Energy Facilities," Code of Federal Regulations, as amended.

Fowler, K. D., 1998, "Waste Compatibility Assessment of 222-S Laboratory Waste (222-S-98-3) with Tank 241-SY-102 Waste via Double Contained Receiver Tank 244-S for Project W-178 Hydrolancing," (Interoffice Memo \#7A150-98-037 with attachment to R. E. Larson, August 26), Lockheed Martin Hanford Corporation, Richland, Washington.

Hirzel, D. R., 1999, "Plutonium Finishing Plant Waste Volume Projection for the Period FY 1999-2028," (Memo \#15530-99-DRH-002 to J. N. Strode, Lockheed Martin Hanford Corporation, January 6), B\&W Hanford Company, Richland, Washington.

HNF-3608, 1998, 222-S Double Container Receiver Tank Facility Integrity Assessment Report, Rev. 0, COGEMA Engineering Corporation, Richland, Washington.

HNF-4483, 1999, Interface Control Document Between the Tank Farm System and 222-S Laboratory, Rev. 0, Numatec Hanford Corporation, Richland, Washington.

HNF-4486, 1999, Interface Control Document Between the Double-Shell Tanks (DST) System and the Plutonium Finishing Plant (PFP), Rev. 0, Numatec Hanford Corporation, Richland, Washington.

HNF-5109, 1999, Phase 2 Rebaseline Report for Tank Farm Restoration and Safe Operations Project $W-314$, Rev. 0, Lockheed Martin Hanford Corporation, Richland, Washington.

HNF-5254, 2000, DST Transfer System Piping Compliance, Rev. 0, CH2M HILL Hanford Group, Inc., Richland, Washington.

HNF-SD-W420-CDR-001, 1998, Project W-420 Stack Monitoring System Upgrades Conceptual Design Report, Rev. 1, Numatec Hanford Corporation, Richland, Washington.

HNF-SD-WM-ER-029, 1999, Operational Waste Volume Projection, Rev. 25, Lockheed Martin Hanford Corporation, Richland, Washington.

Resource Conservation and Recovery Act of 1976, 42 USC 6901.

RPP-5044, 2000, River Protection Project FY 2000 Multi-Year Work Plan Summary, Rev. 1, Lockheed Martin Hanford Corporation, Richland, Washington.

Sederburg, J. P., 1999, "Distribution of Draft Meeting Minutes for Potential 244-S DCRT AGA," (Internal Memo \#82400-99-058 with Attachment \#MM-82400-99-007 to P. J. Certa et al., October 19), Lockheed Martin Hanford Corporation, Richland, Washington. 


\section{RPP-5983 REV 0}

WAC 173-303-640, "Dangerous Waste Regulations: Tank Systems," Washington Administrative Code, as amended.

Serrano, O. M. and J. S. Schofield, 1996, Consolidation of Flammable Gas/Slurry Growth Unreviewed Safety Question Issues, dated July 30, Tracking No. TF-96-0433, Fluor Daniel Hanford, Inc., Richland, Washington.

Westcott, J. L., 1998, "Update to S-Plant and Waste Sampling and Characterization Facilities Waste Volume Projection Assumptions," (Letter \#WMH-9860419 to J. N. Strode, Lockheed Martin Hanford Corporation with Attachment "222-S Laboratory Facility Description," December 30), Waste Management Federal Services, Richland, Washington. 
RPP-5983 REV 0

\section{APPENDIX}

DOCUMENTATATION OF COST ESTIMATE 
RPP-5983 REV 0

This page intentionally left blank. 


\section{INTERNAL MEMORANDUM}

Date: $\quad$ March 23, 2000

To: $\quad$ Douglas C. Larsen

CH2M HILL Hanford Group, Inc.

From: J. Pete Sederburg Thispage intentionally left blank.
$\mathrm{H} \& \mathrm{~N}$

Subject: Confirmation of Cost Data

This memorandum is to confirm the information you provided to me during a telephone conversation on or about December 21, 1999.

As we discussed, I am preparing a problem assessment for a formal decision on the future of the 244-S double-contained receiver tank (DCRT). In response to my request, you provided an estimated yearly cost for the normal operations and maintenance of the 244-S DCRT. Your estimate was $\$ 100,000$ per year with no escalation.

Please sign and date this memorandum to confirm our conversation and to verify that you provided the stated estimate.

Thanks so much for your assistance in this matter.

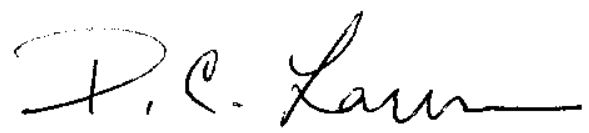


RPP-5983 REV 0

This page intentionally left blank. 


\section{DISTRIBUTION}

Onsite

Reading Room

Pacific Northwest National Laboratories

Hanford Technical Library

$\underline{\text { Subcontractors }}$

DeWeese, G. C., MACTEC

Root, R. W., Jr., Informatics

Sederburg, J. P., ARES Corp. (11)

Treat, R. L., MACTEC

Lockheed Martin Services, Inc.

Rice, R. L.

Central Files

Document Processing Center

Numatec Hanford Corporation

Certa, P. J. (2)

Choho, A. F.

Galbraith, J. D.

Millsap, W. J.
P8-55

R3-73

R3-73

H2-53

R2 -53

R3-73

H6-64

B1-07

A3-94

R3-73

R3-73

R3-73

R3-73

Distr-1 


\section{DISTRIBUTION (CONT)}

CH2M HILL Hanford Group, Inc.

$\begin{array}{ll}\text { Allen, D. I. } & \text { R2-50 } \\ \text { Badden, J. J. } & \text { S5-07 } \\ \text { Bailey, J. W. } & \text { R3-25 } \\ \text { Brown, T. M. } & \text { S5-05 } \\ \text { Bryan, C. B. } & \text { R2-58 } \\ \text { Carpenter, K. E. } & \text { R3-47 } \\ \text { Defigh-Price, C. } & \text { R2-12 } \\ \text { Dodd, R. A. } & \text { R3-72 } \\ \text { Doeler, J. N. } & \text { T4-07 } \\ \text { Erlandson, B. G. } & \text { R1-51 } \\ \text { Fowler, L. D. } & \text { R2-11 } \\ \text { Fredenburg, E. A. } & \text { R1-56 } \\ \text { Hopkins, H. R. } & \text { R2-58 } \\ \text { Hunt, J. W. (3) } & \text { R2-12 } \\ \text { Kirch, N. W. } & \text { R2-11 } \\ \text { Kison, P. F. } & \text { T4-07 } \\ \text { Larsen, D. C. } & \text { T-408 } \\ \text { Lentsch, J. W. } & \text { R3-25 } \\ \text { Miller, P. C. } & \text { R1-51 } \\ \text { Popielarczyk, R. S. } & \text { R2-58 } \\ \text { Powell, R. W. } & \text { R3-75 } \\ \text { Rasmussen, O. R. } & \text { R3-73 } \\ \text { Saueressig, D. J. } & \text { S7-01 } \\ \text { Stanton, G. A. } & \text { S7-01 }\end{array}$

